\title{
The problems of the late implementation of the legal prevention measures for flood risk
}

\author{
Valérie Sanseverino-Godfrin ${ }^{1, a}$ \\ ${ }^{1}$ Mines-Paristech - PSL Research University - Centre de recherches sur les Risques et les Crises, CS 10907, 06904 Sophia- \\ Antipolis Cedex, France
}

\begin{abstract}
Three main laws, 13th July 1982, 2nd February 1995 and 30th July 2003, have reformed the French legal framework and introduced special measures to prevent flood risks. Besides, completing these measures, the urban planning law have imposed since the 1987 Law that the urban planning documents have had to take into account the natural hazards to define the buildable areas. But, the late implementation of the prevention provisions and the lack of the urban planning documents concerning the natural hazards have led to a development of the urbanism in the flood prone areas. As consequences, most of the constructions are not flood proof, and many large damages are caused each time a flood occurs. We present this problematic through 8 municipalities in three departments (Aude, Gard, and Var).
\end{abstract}

\section{Context}

According to the French Ministry of Ecology, involved in the natural hazard prevention policy, more than 17 million people are exposed to flood risk (overflow) in France, that is to say one person out of four and 1.4 million people are exposed to marine submersion [1]. The flood risks in Mediterranean areas are mostly flash flood risks, there are defined as: the level of the rainfall may be more than 200 millimetres within 24 hours or 200 millimetres within 6 hours for some extreme events [2]; , the kinetic and the flow velocity are fast, with a short time to e alert and evacuate the people. The floods are a natural phenomenon that can be hardly prevented and the anthropogenic activities and climate change contribute to increase the likelihood and adverse impacts [3]. Indeed, the urbanism has often been developed in floodable zones, which is one of the major factors of the rise in human and material damages. In its report "Environmental Signals" [4], the European Environment Agency indicates that between 1980 and 2000, the urban area in Europe has increased by $20 \%$ and in Southern Europe, most of this growth is located in territory potentially impacted in particular by floods [5]. The exposure to flood risk is paradoxically linked with positive natural amenities: to live near a river for the sight, the beauty of the landscape. Moreover, the riversides have been key zones for the economic activities and in particular for the commercial activities, which has fostered irreversibly the urban development. The concentration of the people and goods in the zones exposed to natural hazards explain the high tribute in case of disaster [6]. In this situation, the flood prevention is critical for the safety of people and goods. Besides, the control of urban development in floodprone areas and the flood mitigation for the buildings and activities already sited in these areas are one of the problems that the public authorities have to cope with and for which they have to set adapted prevention policies. As Pottier et al. [7] noticed, the traditional solution to these problems is to try to use land use planning or building regulation systems or both to prevent the conversion of areas liable to flooding to urban land uses. The 2007 Directive concerning flood management has imposed for all the member States to elaborate flood management plans, which concern in particular measures "to reduce the probability of flooding and its consequences and address all phases of the flood risk management cycle, focusing particularly on preventing damages by avoiding constructions of houses and industries in present and future flood-prone areas or by adapting future developments to the risk of flooding". Moreover, it is also necessary to provide special prescriptions to building structures, infrastructures and activities erected in flood-prone areas [5].

In order to understand the French concerns regarding the damages in urban areas caused by the floods, we first explain the legal framework that concerns the flood prevention, the urban development and the natural disaster insurance. The three are linked and define the way to prevent and compensate the damages caused by natural hazards in general. The prevention section within the legal framework is relatively old and has regularly evolved since its creation particularly at the end of the $\mathrm{XX}^{\circ}$ century and the beginning of the $\mathrm{XXI}^{\circ}$ century. The first legal provision was instituted by a decree-law in 1935 (30 October) with the Submersible Surface Plan (Plan de Surface Submersible - PSS). This provision was under the responsibility of the French State. The aim of the PSS was to allow water to flow freely. In order to achieve this aim, the PSS implied first to identify the flood-prone areas and then to control the urbanisation in these areas. However, the PSS only addressed to the main rivers in France (Seine, Rhône, Garonne...) and the provision was not applied to small rivers.

A second provision was instituted in 1955 in the article R. 111-3 of the French Urban Code: the Risk Perimeter led the Prefect to identify the areas exposed to natural hazard (all types of natural hazards and not only the flood) and to control the future urbanisation in these areas. It was a provision under the responsibility of the prefects of the departments which was very simple and quick to use, and allowed the implementation of certain building rules to cope with the natural hazards (e.g. a minimum of two stories in flood-prone areas) as well as the prohibition of constructions in highly exposed areas.

\footnotetext{
${ }^{\text {a }}$ Corresponding author: valerie.godfrin@mines-paristech.fr
} 
The real beginning of the natural hazard policy was with the 13 July 1982 Law, which instituted a natural hazard compensation and the Natural Hazard Exposition Plan (Plan d'Exposition aux Risques Naturels - PER). The PER, under the competence of the prefects of the departments, addressed all natural hazards, except forest fire. The aims of the PER were to identify and delineate areas exposed to natural hazards: the "red zones" highly exposed to natural hazards where the future constructions and activities were forbidden; the "blue zones" moderately or lightly exposed to natural hazards where the constructions and the activities could be authorised with prevention prescriptions; the "white zones" not exposed to natural hazards. Moreover, the PER bylaw could impose prevention or protection measures concerning the existing buildings and activities, to enhance people's safety. The prevention measures based on the elaboration of the PER was linked with the insurance of damages caused by natural disasters (it is still linked to the prevention provision with the PPR - see below). The insurance is specific for natural disasters and is based both on the solidarity and the insurance technics. The compensation covers the disaster caused by the "abnormal intensity of a natural factor", for the noninsurable risks and in case of the failure of prevention measures. So, in principle, the compensation is given only when the prevention measures have been set up but they are not sufficient regarding the exceptional characteristic of the natural event. To be insured against material damages caused by natural disasters, people are insured for their goods (properties, economic activities, vehicles). An additional premium is paid but it is not calculated regarding the level of risk: each insured person pays this additional premium according to a rate set by the government, whatever the exposition to natural hazard. In case of natural disaster, an interministerial committee analyses whether the event corresponds with the definition of "the abnormal intensity of a natural factor". If so, an interministerial decree of natural disaster (arrêté de catastrophe naturelle) is enacted, this leads the insurers to give the compensation.

Furthermore, in 1987, the Law concerning the civil security organisation (22 July), the forest protection and the major hazard prevention, made a link between the natural hazard prevention measures and the urban planning documents. Since 1987, these documents have had to take into account the natural (and also technological) hazards to determine the possibility to develop the urbanism.

In spite of this prevention framework based on the PSS, article R. 111-3 of Urban Code and PER, the urban development was not stopped in flood-prone areas and in 1994 (2 February) a circular from the central government reminded the Prefects of strengthening the floodplain policy.

In 1995, a new law concerning the enhancement of the environmental protection brought a reform in the legal natural hazard prevention framework. The Natural Hazard Prevention Plan (Plan de Prévention des Risques - PPR) procedure replaced the PSS, article R
111-3 and PER. It has been envisaged on the same model as the PER aims and principles. The objective is to delineate the areas exposed to natural hazards and to provide mitigation and prevention measures to protect people and the goods. The PPR, under the competence of the prefects of the departments, is a centrally directed set of arrangements applied at the level of the municipalities. The procedure to elaborate a PPR implies first a decree from the prefect to prescribe the PPR, indicating in particular the natural hazards and the municipalities concerned. Then, the study of the PPR project begins and a draft of the future PPR is elaborated and submitted to a public survey (an administrative procedure that aims to collect the public opinion on the project) and to a consultation involving diverse administrative institutions. In a last phase, the draft, amended with the comments of the population and the administrative institutions, is approved by a prefectoral decree. The prefects working with the Territory Departmental Services (Direction Départementale des Territoires - DDT- a representation at the departmental scale of the Ministry of Ecology) elaborate the maps delimiting hazard zones, provide the corresponding land use zoning and prevention and protection measures [8]. To elaborate the PPR, the prefects and the DDT can use the Methodological guides concerning PPR, written by the Ministry of Ecology. The PPR bylaw may impose, for example, to the municipalities the structural measures to be set (e. g. dikes) and for the property owners, the type of construction materials, the structural features of the construction and also the occupancy and the use of buildings. In the zones regulated by a PPR, property owners have to implement the PPR prescriptions, to enhance the safety of the future constructions and activities and also for the existing buildings and activities. But, for the existing ones, the cost of the prevention or protection works does not have to exceed $10 \%$ of the building's value.

The 2003 Law has reinforced the prevention framework, especially concerning the flood risk with provisions like the public information, the restoration of the flooding areas.

Besides, to define the use of territory in the urban planning documents by taking into account the floodprone areas is also a prevention measure. Indeed, the control of urban development is considered as one of the central means to prevent urban flood disasters [9]. If there is no PPR, prescriptions provided by the 1987 Law imply that the urban planning documents define the urban development considering the risk areas in particular the flood-prone areas. When a PPR has been set up, according to the hierarchy of the French norms, the Local Urban Plans (Plan d'Occupation des Sols POS - replaced now by Plan Local d'Urbanisme - PLU) must take into account the PPR as a superior document. So, the POS/PLU must comply with this state specific risk regulation. In both situations, the Mayor, the public authority competent in urbanism, has to delineate the risky zones and to provide special prescriptions for the buildings and activities to be implemented in these zones, if the level of risk allows this implementation. 
Many judgments of the French administrative courts have systematically sanctioned the mayors for issuing building permits in flood-prone areas, where the high risk was known or for issuing the permits without specific prescriptions concerning the flood mitigation to decrease the vulnerability of the constructions (e.g. State Council., 2 October. 2002, Min. de l'équipement, des transports et du logement, $\mathrm{n}^{\circ} 232720$; Administrative Appeal Court, Douai, 2 February 2012, M. et Mme Rémi A., n 10DA01448).

Besides, since 2002, the Flood Prevention Action Programs (Programmes d'Action de Prévention des Inondations - PAPI) aim to promote an integrated management of the flood risk, to reduce the damages on the human health, the goods and the economic activities. One of the objectives is to take into account the flood event in the urbanism (axis 4 of the Program) and to impose the actions to reduce the vulnerability of the persons and the goods (axis 5 of the Program).

So, in principle, in flood-prone areas, highly exposed, the urban development is no more possible, especially in the communities which have been flooded several times. In the moderately or lightly exposed flood-prone zones, the urbanisation is possible but with some mitigation prescriptions for the activities and the buildings, so that they are less vulnerable to flood, a way to learn to "live with floods" [10]. In the reality, the late implementation of the legal framework concerning the prevention of this type of risk, the lack of control of urban development in flood-prone areas and of the adaptation of the constructions to the flood risk seem to be the main causes of the numerous and huge damages caused by the floods. The aim of this study is to show the delay and the lack of the enforcement of flood prevention policy at a local scale, in areas often impacted by floods, despite a prevention policy defined at a national scale. The consequences of this lack and delay are an urban development in flood prone areas and numerous events classified as "natural disaster", because of the huge damages they cause. We present this problematic through 8 municipalities in three departments: Cuxac d'Aude, VilleneuveMinervois (Aude); Alès, Bagnols-sur-Cèze, Sommières (Gard); Fréjus, Puget-sur-Argens, Roquebrune-surArgens (Var), which were severely impacted by the floods, respectively in 1999, 2002 and 2003, 2010 and 2011 and 2014. The interest of this study for the practitioners is to show the obvious necessity to implement prevention measures and to control the urban development in the flood prone areas to decrease the impacts of the flood events, in addition in a context of climate change that may increase the occurrence of extreme events like torrential rains and flash floods.

This paper presents the first results of two research projects: Retina (financial supporter: French Ministry of Ecology) and MobiClimex (financial supporter: Agence Nationale de la Recherche). Our study addresses the implementation of the flood prevention measures, especially the PPR and the urban policy.

\section{Methodology}

To make our analysis, we need to know the different flood events that occurred in the case study territories, the prevention provisions that have been set up before 1995 (PSS, article R 111-3, PER) and after 1995 (PPR), the way the urban planning documents have taken into account the flood and which measures to decrease the vulnerability of the buildings have been implemented.

The first step of our analysis consists in knowing whether the state public authorities quickly set up the prevention provision considering the frequent flood events. The information concerning the flood events and the prevention measures are listed in a public data base, GASPAR, elaborated by the Ministry of Ecology and freely available on the web. Concerning particularly the flood events, GASPAR contains data of the natural disaster interministerial decrees ("arrêtés de catastrophe naturelle"). The data are presented by departments and in each department by municipalities. For each municipality, the information concerning the interministerial decrees are: natural hazard, date of the beginning of the event, date of the end of the event, date of the decree, date of the publication in the Official Journal (Journal Officiel where are published all the French legal texts). So, we extract from this data base the information concerning the events that occurred in the three departments - Aude, Gard, and Var - and for the studied municipalities. The problem of this data base is that it contains partial information about the natural disasters that occurred in the past. This information concerns the natural events that have been legally recognised as "natural disasters" by the interministerial decrees since 1982. Before this date, the information about the natural events was not collected systematically. Moreover, the natural events which do not cope with the definition of an "abnormal intensity of a natural factor" (e.g. small-scale events) and that are not considered as a "natural disaster" by an interministerial decree, are not in the data base. But, we can considerer that the small-scale events do not cause enough impacts to question about the urban development in the impacted zones. These lacks of data do not hinder the analysis because, what we want to demonstrate is that in spite of a natural hazard prevention policy, the prevention measures has been implemented with delay and that fact allows the urban development in flood-prone areas. And the flood events that have occurred since 1982 are sufficient to make the demonstration of a late implementation of the prevention measures that have been an influence on the urban development in floodable zones. For the Gard department, we complete the information with data publicized by NOE, a website (http://www.noe.gard.fr/) of the Gard Departmental Council. NOE gives information of flood events, collected thanks to historical archives. The first listed event occurred in 1295. However, considering our study, we extract from NOE only the flood events from 1935 that is to say from the date of the first legal provision, the PSS. 
We also extract from GASPAR data about the prevention provisions concerning the case study territories: PSS, article R 111-3, PER and PPR. The information presents the type of prevention provisions, the date of the beginning of the procedure, the date of the public survey, the date of the prevention provision approval, the risk basin which is concerned by the prevention provision.

The analysis gathering the data concerning the natural disaster decrees and the prevention provisions allows knowing whether the prevention provisions have been early set up considering the high exposure to flood risk of the studied municipalities. In principle, to avoid the frequent damages and to protect people and the goods and also to control the development of the urban area, it is assumed that the prefects quickly implemented the prevention provisions, in particular after the reform brought by the 1995 Law.

The second step of our analysis consists in knowing whether the urban planning documents regarding the 1987 Law have taken into account the flood-prone areas to delineate the buildable zones. The information concerning the urban planning documents (POS and PLU) is available on the website of most of the municipalities. It is possible to download the zoning and the urbanism bylaw. If it is no available on the web, it is possible to get the data from the DDT or from the urban office of the municipalities, but in this case, the data is often in paper form. So, the problem is to get a copy of the data but thanks to numerical camera, we can collect the information with a good quality of picture. A second problem is to use the data, especially the map that cannot be superimposed with other ones. So, we can only do a visual analysis to make a comparison between the delineation of the building zones and the floodable zones. For these ones, we use the data from the zoning of the prevention provision, in particular the zoning of the PPR. This one is available freely on internet, on the DDT website or on the municipality website. With the different maps of the POSs, PLUs and PPRs, we can see the delineation of the buildable zones and the delineation of the flooding zones. It is so possible to analyse whether the urban development has taken place in the flood-prone areas.

But, it is possible to build in a moderately or lightly exposed to flood risk zone. That is why it is necessary to complete our analysis with a third step which consists in knowing whether the flood risk has been taken into account to define the mitigation flood measures that allow decreasing the vulnerability of the constructions situated in the flood-prone areas. The urbanism bylaw and the PPR bylaw contain prescriptions concerning the mitigation flood measures. This type of bylaws is downloadable on the website of most of the municipalities and if not, it is possible to get the data from the DDT or from the urban office of the municipalities, in paper form.

\section{Results}

Our first result addresses the number of flood events occurred in the case study departments and municipalities. In the three following tables are listed the date of the flood events and the date of the prevention provision set up in each municipality.

\begin{tabular}{|c|c|c|}
\hline \multirow{3}{|c|}{ Aude department } \\
\hline \multirow{2}{*}{ Municipalities } & Cuxac d'Aude & $\begin{array}{c}\text { Villeneuve- } \\
\text { Minervois }\end{array}$ \\
\hline & $10 / 14 / 1986$ & $01 / 25 / 1992$ \\
\cline { 2 - 3 } & $01 / 25 / 1992$ & $06 / 24 / 1992$ \\
\cline { 2 - 3 } & $09 / 27 / 1992$ & $09 / 27 / 1992$ \\
\cline { 2 - 3 } Flood events since & $11 / 01 / 1993$ & $10 / 16 / 1992$ \\
\cline { 2 - 3 } 1982 recognised as & $10 / 19 / 1994$ & $11 / 14 / 1999$ \\
\cline { 2 - 3 } “natural disaster" & $03 / 03 / 1995$ & $11 / 17 / 1999$ \\
\cline { 2 - 3 } source GASPAR) & $01 / 29 / 1996$ & $09 / 30 / 2002$ \\
\cline { 2 - 3 } & $12 / 12 / 1996$ & $09 / 05 / 2005$ \\
\cline { 2 - 3 } & $11 / 14 / 1999$ & $01 / 27 / 2009$ \\
\cline { 2 - 3 } & $11 / 15 / 2005$ & $01 / 28 / 2009$ \\
\cline { 2 - 3 } & $02 / 01 / 2006$ & $03 / 16 / 2011$ \\
\cline { 2 - 3 } & $01 / 27 / 2009$ & $10 / 31 / 2012$ \\
\hline PSS & $12 / 01 / 2014$ & \\
\hline Art. R 111-3 & $12 / 02 / 1949$ & $/$ \\
\hline PER & $/$ & $/$ \\
\hline PPR & Prescribed & Prescribed \\
\hline & $03 / 07 / 1996-$ & $01 / 10 / 2000-$ \\
& Approved & Approved \\
\hline & $11 / 12 / 2008$ & $06 / 22 / 2006$ \\
\hline
\end{tabular}

Table 1: Flood events and prevention provisions in the Aude department.

\begin{tabular}{|c|c|c|c|}
\hline \multicolumn{4}{|c|}{ Gard department } \\
\hline $\begin{array}{c}\text { Municipa } \\
\text { lities }\end{array}$ & Alès & $\begin{array}{l}\text { Bagnols- } \\
\text { sur-Cèze }\end{array}$ & Sommières \\
\hline \multirow{15}{*}{ 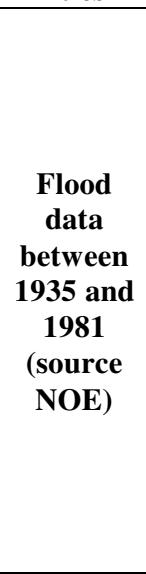 } & $11 / 20 / 1935$ & $11 / 17 / 1935$ & $11 / 20 / 1935$ \\
\hline & $11 / 01 / 1937$ & $01 / 07 / 1955$ & $11 / 01 / 1937$ \\
\hline & $10 / 17 / 1943$ & $02 / 01 / 1955$ & $09 / 08 / 1938$ \\
\hline & $10 / 28 / 1951$ & $12 / 25 / 1957$ & $01 / 21 / 1941$ \\
\hline & $11 / 10 / 1951$ & $09 / 30 / 1958$ & $10 / 25 / 1943$ \\
\hline & $00 / 07 / 1955$ & $11 / 06 / 1963$ & $05 / 30 / 1946$ \\
\hline & $02 / 01 / 1955$ & $09 / 13 / 1976$ & $05 / 25 / 1948$ \\
\hline & $01 / 01 / 1956$ & $10 / 24 / 1977$ & $10 / 29 / 1951$ \\
\hline & $09 / 30 / 1958$ & & $10 / 14 / 1953$ \\
\hline & $10 / 04 / 1958$ & & $09 / 30 / 1958$ \\
\hline & $01 / 01 / 1960$ & & $10 / 31 / 1963$ \\
\hline & $10 / 31 / 1976$ & & $02 / 24 / 1969$ \\
\hline & $05 / 08 / 1979$ & & $10 / 25 / 1976$ \\
\hline & & & $12 / 31 / 1976$ \\
\hline & & & $12 / 31 / 1978$ \\
\hline \multirow{11}{*}{$\begin{array}{c}\text { Flood } \\
\text { events } \\
\text { since } \\
1982 \\
\text { recognise } \\
\text { d as } \\
\text { “natural } \\
\text { disaster" } \\
\text { (source } \\
\text { GASPAR } \\
\text { ) }\end{array}$} & $10 / 14 / 1983$ & $10 / 14 / 1983$ & $10 / 03 / 1988$ \\
\hline & $07 / 16 / 1987$ & $10 / 12 / 1990$ & $09 / 23 / 1992$ \\
\hline & $10 / 29 / 1987$ & $09 / 23 / 1992$ & $09 / 24 / 1994$ \\
\hline & $11 / 11 / 1988$ & $09 / 25 / 1993$ & $10 / 21 / 1994$ \\
\hline & $09 / 25 / 1993$ & $10 / 21 / 1994$ & $10 / 07 / 2001$ \\
\hline & $10 / 06 / 1995$ & 10/06/1995 & $09 / 10 / 2002$ \\
\hline & $10 / 07 / 1997$ & $08 / 05 / 1996$ & $12 / 13 / 2002$ \\
\hline & $09 / 10 / 2002$ & $10 / 07 / 1997$ & $09 / 18 / 2014$ \\
\hline & $09 / 20 / 2014$ & $05 / 28 / 1998$ & $09 / 30 / 2014$ \\
\hline & $09 / 13 / 2015$ & $09 / 10 / 2002$ & \\
\hline & & $12 / 01 / 2003$ & \\
\hline
\end{tabular}




\begin{tabular}{|c|c|c|c|}
\hline & & $11 / 05 / 2011$ & \\
\hline & & $10 / 10 / 2014$ & \\
\hline & & $09 / 13 / 2015$ & \\
\hline & & & \\
\hline PSS & I & I & I \\
\hline $\begin{array}{c}\text { Art. } R \\
111-3\end{array}$ & 1 & I & l \\
\hline PER & 1 & 1 & 1 \\
\hline PPR & $\begin{array}{l}\text { Prescribed } \\
\text { 08/31/2001 } \\
\text { - Approved } \\
11 / 09 / 2010\end{array}$ & $\begin{array}{l}\text { Prescribed } \\
\text { 11/07/1995 } \\
\text { - Approved } \\
03 / 10 / 2000\end{array}$ & $\begin{array}{l}\text { Prescribed } \\
12 / 17 / 2004 \\
\text { - Approved } \\
07 / 03 / 2008 \\
\end{array}$ \\
\hline
\end{tabular}

Table 2: Flood events and prevention provisions in the Gard department.

\begin{tabular}{|c|c|c|c|}
\hline \multicolumn{4}{|c|}{ Var department } \\
\hline $\begin{array}{c}\text { Municipa } \\
\text { lities }\end{array}$ & Fréjus & $\begin{array}{c}\text { Puget-sur- } \\
\text { Argens }\end{array}$ & $\begin{array}{l}\text { Roquebrune } \\
\text {-sur-Argens }\end{array}$ \\
\hline \multirow{25}{*}{$\begin{array}{c}\text { Flood } \\
\text { events } \\
\text { since } \\
1982 \\
\text { recognise } \\
\text { d as } \\
\text { "natural } \\
\text { disaster" } \\
\text { (source } \\
\text { GASPAR } \\
\text { ) }\end{array}$} & $08 / 24 / 1983$ & $11 / 07 / 1984$ & $24 / 08 / 1983$ \\
\hline & 10/11/1987 & $11 / 17 / 1990$ & $11 / 07 / 1984$ \\
\hline & 10/17/1990 & $01 / 12 / 1994$ & $10 / 11 / 1987$ \\
\hline & $01 / 25 / 1991$ & $01 / 14 / 1996$ & $10 / 12 / 1990$ \\
\hline & 09/23/1992 & $09 / 25 / 2006$ & 09/24/1993 \\
\hline & 09/27/1992 & $12 / 03 / 2006$ & 10/06/1993 \\
\hline & $10 / 06 / 1993$ & $09 / 18 / 2009$ & $10 / 07 / 1993$ \\
\hline & $01 / 12 / 1994$ & $06 / 16 / 2010$ & $01 / 12 / 1994$ \\
\hline & $06 / 26 / 1994$ & $11 / 10 / 2011$ & $11 / 06 / 1994$ \\
\hline & $01 / 14 / 1996$ & $10 / 26 / 2012$ & $01 / 14 / 1996$ \\
\hline & $08 / 12 / 2005$ & $01 / 20 / 2014$ & $09 / 30 / 2000$ \\
\hline & $12 / 03 / 2006$ & $11 / 27 / 2014$ & $11 / 06 / 2000$ \\
\hline & $09 / 19 / 2009$ & $09 / 13 / 2015$ & $09 / 25 / 2006$ \\
\hline & $05 / 04 / 2010$ & $10 / 03 / 2015$ & $12 / 03 / 2006$ \\
\hline & $06 / 16 / 2010$ & & $09 / 18 / 2009$ \\
\hline & $06 / 21 / 2010$ & & $09 / 19 / 2009$ \\
\hline & $11 / 10 / 2011$ & & $06 / 16 / 2010$ \\
\hline & $01 / 20 / 2014$ & & $11 / 10 / 2011$ \\
\hline & $11 / 27 / 2014$ & & $11 / 09 / 2011$ \\
\hline & $10 / 03 / 2015$ & & $03 / 01 / 2012$ \\
\hline & & & $06 / 26 / 2012$ \\
\hline & & & $01 / 10 / 2013$ \\
\hline & & & $01 / 10 / 2014$ \\
\hline & & & $11 / 27 / 2014$ \\
\hline & & & $09 / 13 / 2015$ \\
\hline PSS & 1 & 1 & 1 \\
\hline $\begin{array}{c}\text { Art. R } \\
111-3\end{array}$ & 1 & 1 & I \\
\hline PER & 1 & 1 & 1 \\
\hline PPR & $\begin{array}{l}\text { Pédegal/Val } \\
\text { escure } \\
\text { Prescribed } \\
04 / 10 / 2000 \\
\text { - Approved } \\
05 / 06 / 2002 \\
\\
\text { Argens/Ver } \\
\text { nède/Reyran } \\
\text { Prescribed } \\
09 / 08 / 2010 \\
\text { - Approved } \\
03 / 01 / 2012 \\
\text { reviewed } \\
03 / 26 / 2014\end{array}$ & $\begin{array}{l}\text { Prescribed } \\
\text { 09/08/2010 } \\
\text { - Approved } \\
\text { 12/20/2013 }\end{array}$ & $\begin{array}{l}\text { Prescribed } \\
\text { 09/08/2010 } \\
\text { - Approved } \\
12 / 20 / 2013\end{array}$ \\
\hline
\end{tabular}

Table 3: Flood events and prevention provisions in the Var department.
As we can see in the three tables, for each department, numerous flood events occurred. The impacts of some of them (fatalities and high costs of damages) were particularly dramatic so that they became a flood reference for the impacted territory: the 1999 flood in the Aude department (36 fatalities, 340 million $€$ damages) [11]; the 2002 flood in the Gard department (22 fatalities, 830,6 million $€$ damages) [12]; the 2010 flood in the Var department (25 fatalities, 1,2 milliard $€$ damages) [13].

Concerning the Aude department, we can see that despite a PSS in 1949 concerning the Aude River and in particular the territory of Cuxac d'Aude, numerous floods caused later on damages, so that they were classified as "natural disasters" by interministerial decrees. No Perimeter of risk (article R. 111-3 of Urban Code) was instituted. Moreover, none of PER was set up. Considering the natural disaster decrees, two largescale floods, impacting several municipalities, seem to have occurred before 1999: in January 1992 and in September 1992, without initiating a PER procedure, nor PPR. We can also notice that the PPR procedure begins lately regarding the flood disaster occurred since 1982: after 7 flood events classified as "natural disaster" for Cuxac d'Aude and Villeneuve-Minervois. Concerning this municipality, the PPR was prescribed just after the huge disaster of the 1999 flood. For Cuxac d'Aude, the PPR was prescribed in March 1996. The procedure of the two PPRs lasts a long time: respectively 12 years and 11 months, 6 years and 5 months before the approbation of the Cuxac d'Aude and Villeneuve-Minervois PPR. During this time, 4 flood events occur in Cuxac d'Aude and 2 in VilleneuveMinervois. After the approbation of the two PPRs, 2 flood events were classified as natural disasters for Cuxac d'Aude and 4 for Villeneuve-Minervois.

Concerning the Gard department, we can notice the same characteristics. As we get more information about the flood events before 1982, we can see that the department is a territory very frequently impacted by floods. Two large-scale floods, impacting several municipalities, seem to have occurred: in November 1935 and in September 1938. The Rhône River borders the department; however none of PSS was set up. No Perimeter of risk (article R. 111-3 of Urban Code) was instituted. Moreover, in spite of the numerous flood events, none of PER was implemented. The PPR procedure began lately: after 7 flood events classified as natural disasters (since 1982) for Alès; after 6 for Bagnols-sur-Cèze and after 7 for Sommières. The procedure before the approbation of the PPRs lasts a long time: respectively 9 years and 3 months, 4 years and 4 months, and 3 years and 7 months for Alès, Bagnols-sur-Cèze and Sommières. During this time one flood event occurs in Alès, 3 in Bagnols-sur-Cèze. After the approbation of the PPR, 2 flood events occur in Alès, 5 in Bagnols-sur-Cèze and 2 in Sommières.

No main River borders or flows through the Var department, which was not concerned by the PSS procedure. No Perimeter of Risk, neither PER were set up despite the occurrence of flood events. Considering the natural disaster decrees, three large-scale floods, 
impacting several municipalities, seem to have occurred: in October 1990, in January 1994 and in January 1996, but without initiating the PER procedure, nor the PPR one. The PPR procedure began after 7 flood disasters occurred since 1982 in Puget-surArgens, 10 in Fréjus and 11 in Roquebrune-sur-Argens. We can notice that just after the disaster in June 2010, 3 PPR was prescribed in September. The procedure lasts only 2 years and 1 month for the PPR concerning the Pédégal/Valescure basin in Fréjus. For the PPRs prescribed just after the June 2010 disaster, the procedure was very fast: between 2 and 3 years and 5 months. During this time, 2 flood disasters occurred in Puget-sur-Argens, one flood in Roquebrune-sur-Argens. After the approbation of the PPRs, 3 flood disasters occur in Fréjus and Roquebrune-sur-Argens, 4 in Pugetsur-Argens.

\begin{tabular}{|l|l|c|}
\hline & \multicolumn{2}{|c|}{ Aude } \\
\hline & $\begin{array}{l}\text { Cuxac } \\
\text { d'Aude }\end{array}$ & $\begin{array}{l}\text { Villeneuve- } \\
\text { Minervois }\end{array}$ \\
\hline POS & $10 / 09 / 1987$ & $/$ \\
\hline PLU & $06 / 04 / 2015$ & $04 / 25 / 2012$ \\
\hline
\end{tabular}

Table 4: Dates of the urban planning documents of the municipalities of the Aude department

\begin{tabular}{|l|l|l|l|}
\hline & \multicolumn{3}{|c|}{ Gard } \\
\hline & Alès & $\begin{array}{l}\text { Bagnols- } \\
\text { sur-Cèze }\end{array}$ & Sommières \\
\hline POS & $05 / 08 / 1979$ & $02 / 15 / 1985$ & $08 / 09 / 1983$ \\
\hline PLU & $06 / 24 / 2013$ & $02 / 13 / 2006$ & $02 / 26 / 2008$ \\
\hline
\end{tabular}

Table 5: Dates of the urban planning documents of the municipalities of the Gard department

\begin{tabular}{|l|l|l|l|}
\hline & \multicolumn{3}{|c|}{ Var } \\
\hline & Fréjus & $\begin{array}{l}\text { Puget-sur- } \\
\text { Argens }\end{array}$ & $\begin{array}{l}\text { Roquebrune- } \\
\text { sur-Argens }\end{array}$ \\
\hline POS & $02 / 08 / 1980$ & $11 / 12 / 1982$ & $03 / 30 / 1990$ \\
\hline PLU & $01 / 19 / 2005$ & $03 / 21 / 2013$ & In progress \\
\hline
\end{tabular}

Table 6: Dates of the urban planning documents of the municipalities of the Var department

Concerning the urban planning documents, as we saw in the tables 4 to 6 , many of them have been elaborated before the 1987 Law. So we can suppose that they do not take into account the natural hazards, especially the flood risk or if so, it is partially taken into account. We present some of the results of the analysis of them which seem to us the most relevant and that give a trend of the way the urban policy take into account the flood risk in Alès, Bagnols-sur-Cèze, Sommières (Gard) and Puget-sur-Argens (Var). All the old studied documents were made at the end of the 70s and the beginning of the 80 's. At this time, it was not yet compulsory for the urban planning documents to take into account the natural hazards. However, the flood risk is mentioned in all the studied documents, but with different level of information which has had consequences on the way to develop the urbanisation considering this type of risk. For example, in Alès, the first urban planning document (POS) was elaborated in May 1979. The urbanism bylaw just indicated one prescription for the location of the buildings: the obligation to build between 8 and 15 meters far from the different dikes whereas the zoning did not take into account the flood prone areas. On the contrary, the floodable zones delineated today in the PPR map concern zones where it was possible to build in the beginning of the 80 's. It appears in the base map of the PPR many constructions in floodable areas that were not indicated in the base map of the POS in 1979. So, these constructions have been built between the beginning of the 80 's and the beginning of the 2000's that is to say paradoxically, during the period when the prevention policy at a national scale has been reinforced. The urban planning document of Bagnolssur-Cèze (May 1983) took into account the flood risk in the delineation of the zoning and in the urbanism bylaw. Most of the flood-prone areas were natural or agricultural areas. However, a significant part of the municipality territory was already built in floodable areas. The reference flood to determine the map and the bylaw is the one that occurred in 1958. So, it is compulsory to build the ground floor above the highest level of the 1958 flood; the urban planning document revision, in 1996, took as reference the 100-year flood, which has modified the delineation of the floodable areas (wider) and the height of the construction design (higher). Concerning Sommières, the urban planning document (October 1979) took also into account the flood risk. Like Bagnols-sur-Cèze, a significant part of the old town borders the Gardon River and so, has been built in floodable areas. In this context, the first urbanism bylaw prohibited the use of the ground floor as a household in the zones near the Gardon River. It was also forbidden to build an extension of a construction in the flood-prone areas. It was mentioned in the urbanism bylaw that the property owner should take all the prevention and mitigation measures against flood risk, but without indicating to them how to do. However, we can make the same comment than for Alès: it appears in the base map of the PPR many constructions in floodable areas that were not indicated in the base map of the POS in 1983. In the case of Sommières like in the case of Alès, the delineation of the floodable zones was not as strict as today and many constructions have been built between the beginning of the 80 's and the beginning of the 2000's and are now exposed to flood risk. In Puget-sur-Argens, the urban planning document has been elaborated in November 1982. Considering the frequent flood in the areas, the zoning and in particular the delineation of flood-prone areas are based on aerial photographs taken during the previous floods and on experience of the elected officials in collaboration with the urbanism state department. The first zoning considered as nonconstructible the plots that were flooded in the previous floods of the Argens and based on a case-by-case examination the land-use permits in the low or moderate exposed areas. Some prescriptions could be imposed such as the ground floor above the level of the flood, the prohibition of the use of the ground floor.

The urban planning documents today have completely taken into account the floods for two 
reasons: the implantation of PPRS and the ALUR Law (March, 24 2014) which has imposed to transform the old urban planning documents (POS) to new ones (PLU) at the latest the $1^{\text {st }}$ of January 2016. This law leads to modify the old urban planning documents and to take into account the PPRs that have been recently elaborated. So urbanism bylaws and the maps are now faithful to the PPR. The PPR zonings and their rules are duplicating in the urban planning document map and the urbanism bylaw. We can notice now a strong coherence between the urban planning documents and the PPR, concerning the control of the urban development and the prescriptions to reduce the vulnerability of the construction in the flood-prone areas.

Furthermore, the prevention provisions through the PPR have the objectives to reduce the vulnerability of the constructions and to control the urbanisation in the flood-prone areas. We examine all the PPRs concerning the case study municipalities and we present here a synthesis of these PPRs. The zonings often make a distinction between the zone presenting a danger (high hazard), the precaution zone (low or moderate hazard). Most of the zonings also indicate the floodable zones because of the breaking or submersion of the dikes. Considering these different zones, the PPR bylaws provide the prescriptions to be applied for the future constructions and activities or the existing ones. We examine particularly the prescriptions concerning the constructions, because a part of the two research projects, Mobiclimex and Retina consists in analysing the building permits and the development of the urban area in floodable zones. Concerning the control of the development of urbanisation in highly exposed areas, the PPR rules prohibit the constructions or activities that obstruct the flow, the constructions which are vulnerable because of their structure or their occupants (e.g. hospital, children's nursery, shopping centre...). The basements, windows below the level of the reference flood, the single-storey buildings, and the constructions for economic activities are also forbidden. In general, all works, earthworks, constructions are forbidden. It is also prohibited to create cellars, underground car parks. It is not possible to implement craft and industrial buildings, warehouses. In the zone moderately or lightly exposed to flood, it is possible to build constructions if they are flood proof and pressure resistant, in particularly the foundations. The ground floor must be elevated above the level of the flood. The electrical network must be split in two to dissociate the part that may be under the water: this allows the safe part of it continuing to function. The fuel tank must be buried or secured to a concrete block. Concerning the existing buildings, the aim of the rules is to impose prescriptions to reduce their vulnerability. For all the buildings in flood-prone areas, the main prescription addresses the construction of an accessible refuge inside the construction whose capacity is adapted to the number of the persons exposed, and with an opening outside that allows the evacuation of these people. The electrical network must be out of the water. The same prescription is applicable for the storage of the pollutants. The part of the constructions that may be under the water must be rebuilt with flood proof materials. The limit of the swimming-pool is marked. The extension of basements is forbidden. It will be not possible to rebuild a construction that has been destroyed by a flood. It is also forbidden to change the use of a construction when the change implies to increase the number of inhabitants. But, an extension of a construction is allowed without the creation of new households. In case of a restoration or rehabilitation work, the level of the floor must be above the level of flood: the height of the sur-elevation depends on the level of the flood in the territory concerned.

\section{Discussion of the results and main conclusions}

The study of the data concerning the flood disaster in the three departments shows that the flood is a recurring phenomenon, in spite of a national prevention policy really initiated in 1982 and of many injunctions of the Ministry of Ecology, through circulars reminding the prefect of implementing the prevention provisions and controlling the urban development (e.g. Circulars 02/02/1994 and 01/24/1994). For example, the 2002 Circular (30 April) reminds the prefect of the French State will to reduce the vulnerability in the flood-prone areas and to control the urban development with the PPR. But, the numerous evolutions of the legal provisions have not fostered a dynamic at a local scale, despite the huge events that occurred and impacted several municipalities situated in a same territory (e.g. January and September 1992 in the Aude department; October 1990, January 1994 and January 1996 in the Var). Government encourages a natural hazard prevention policy, but local developers and municipality community leaders often have other interests and aims. Legally, the Mayors have to protect the citizens against the disasters but they are torn between this mission and the will or necessity to promote economic development of the municipalities. The Mayors are often under several pressures, in particular to develop urbanism, which affects the fact to take into account the flood risk. The local development is a quotidian concern but not the management of natural hazards. The delay for a PPR project to be approved allows the Mayors negotiating the delineation of the zoning, putting in the balance the economic development and the attractiveness of the territory [14]. The floodplain development brings a sort of "rewards": a private profit for individuals through increased land values and higher levels of property-based community taxes for local government, derived from increased employment, regeneration and other local economic change [7]. In this context, it seems that each flood event has been quickly forgotten in the memory of the public authorities and the people living in flood-prone areas. It may be a problem of awareness. But, because of the recent past natural disasters, we are now more 
aware about this problematic and more conscious that natural disasters are not a fatality and we are responsible of the human and material damages, due to the urban development in exposed areas. Indeed, this lack of awareness has had as a consequence a late implementation of the prevention measures and the development of urbanism in the flood areas, and so an increasing in the vulnerability an in the safety of the persons and the goods. This is the overall picture that we can draw regarding the numerous flood disasters that occurred and that have been officially registered since 1982 in the objective of compensating the damages. However, it is important to remind of the fact that the PSS was not provided for the little rivers (the case of the Gardon rivers in the Gard, or the Nartuby and Argens rivers in the Var) and that the PER was a failure [15]. Moreover, the interministerial committee appreciation of the "abnormal intensity" of a natural event to grant the compensation was very lax and loose during a long time [16]. This did not encourage the public authorities to enforce the prevention policy at a local scale and to tighten the control of urban development in flood-prone areas. The public authorities forgot the sought-after link between damage compensation and flood prevention measures, as prescribed in the 1982 Compensation Law [7].

Most of the time, the absence of severe events during several years causes oblivion of the natural hazards and so the public authorities tend to not take into account in their decision concerning the urbanism [14]. It is not until the occurrence of dramatic events to give an impulsion for the enforcement of prevention policy in a territory: 1999 in the Aude; 2002 in the Gard, 2010 in the Var. The problem is that a dramatic event occurred in a territory gives an impulsion only in this impacted territory: in spite of the numerous fatalities and high costs of the damages, the 1999 flood in Aude does not have enforced the flood prevention policy in other departments. The occurrence of an event is not aware of the possibility of a similar event in another department. Moreover, the occurrence of a dramatic event did not accelerate the enforcement of the PPR procedure. The PPR concerning Cuxac d'Aude was prescribed in 1996. In spite of the 5 fatalities caused by the flood in 1999, the PPR was only approved in 2008. We can make the same comment concerning the PPR of Villeneuve-Minervois, prescribed just after the 1999 flood but approved nearly six years later. Concerning Alès, the PPR was prescribed in 2001 and the 2002 flood did not quicken the procedure for the PPR was approved in 2010. The procedure in the Var is an exception: the PPRs in numerous municipalities was prescribed just after the 2010 flood and approved very quickly, within in maximum less than 4 years. In the end, the PPR policy has really had an impulsion in 2000. However, several inequalities can be observed as Vinet notices it [17]. The PPRs have been first set up for territories near the Rivers. The PPRs addresses most of the time the big cities (more than 10,000 inhabitants), but scarcely the little municipalities.
The late implementation of the PPR has three consequences: the lack of implementation of structural measures to protect the exposed territories and to decrease the impact of the flood events, the lack of control of urban development and the lack of mitigation flood measures for the constructions. Urban development in flood-prone areas can lead to issues for both the people and the good within these zones. As we saw, some of the urban planning documents that we studied have early taken into account the flood problematic and delineated flood-prone areas to avoid the urban development in these areas. But, the urban planning documents cannot impose measures to be applied on existing buildings. Moreover, it is a fact that the urbanism in the flood-prone areas has been developed within the three past decades in spite of the legal provisions. The observatory of the flood risk in the Gard, NOE, indicates that 100,000 households have been built in the floodable areas between 1999 and 2008 on the French territory. However, the flood events in the Aude in 1999, in the Gard in 2002 and in the area of the Rhône River in 2003 have lightly slowed the trend. All the parliamentary reports written after a flood disaster have noticed the same lack concerning the urban planning documents: inefficiency of the urban plans [18]; an extension of the urbanism and constructions in new areas but floodable [(13) (18)]; an encroachment in the river beds [12]; an underestimation of the flood risk to develop urbanism in floodable zones [19] ; outdated urban planning documents [(20), (18)] and an absence of initiative to elaborate new ones [(21) (22)]; building permits delivered in floodable zones [18]. However, as Pottier et al. noticed [7], the PER/PPR procedures seem to have avoided most of the times urban land uses in the high hazard areas, but not in the lower risk areas or fail to succeed in promoting damage reduction for existing buildings. So, the main actual problem is the vulnerability of the constructions and consequently the people present within these constructions. Due to the late implementation of PPRs, most of the constructions are not flood proof, which can caused a lot of damages when the flood events occurred: damages to the construction (e.g. wooden blinds and doors, electrical networks, plasterboard...) and/or damages to the furniture and equipment in the households. Beside, parliamentary reports have highlighted the vulnerability of the constructions among the causes of the amount of damages: a change in the use of the constructions, forgetting that the ground floor is floodable whereas it was before unoccupied [19]; a lack of adaptation for the new constructions (no first floor, no crawl space under the construction) [12]. The vulnerability of a plot or a construction may be defined through five parameters and in particular, the flood height and the stability of the construction (the other ones are the road connection, the vulnerability of the inhabitants, the impacts on the other plots) [23]. Recent studies have shown the relevance of an adequate implementation of flood damage mitigation measures for the households, with the aim of flood-proofing buildings that can decrease the costs of floods [(24) (25)]. Poussin et al. [26] also highlight the effectiveness 
of mitigation measures and the material damages that can be noticed in case of lack of prevention and mitigation measures. For Gersonius et al. [27], a solution to avoid increasing the damages is to build resilient constructions, based on five defence or accommodation strategies: elevated configuration (the entire structure is elevated); dry proofing (impervious barriers built into the structure); wet proofing the building (to accept that the water enters the building and so to use materials that help minimize the impact of water); construction of permanent or mobile water barriers (to try to keep flood water out of buildings); floating or amphibious solutions (buildings that can move with the fluctuating water level).

The PPR provisions provide measures to remedy to the vulnerability of the constructions. According to the PPR bylaws, property owners living in floodable zones are required to modify their building designs to be in accordance with the PPR prescriptions: the cost of these works does not exceed $10 \%$ of the building's value. The analysis of the PPR bylaw allows highlighting the main protection and flood mitigation measures (see part 3) but, when the construction is built, it is sometimes difficult or technically impossible to intervene on the constructions to reduce the vulnerability. For example, if the construction is a single storey house, it may be not possible to raise the building and build a first floor, because of the weakness of the foundations or to raise the electrical network above the high water. The problem of the lack of flood mitigation measures is also a problem of safety. Indeed, the absence of a first floor may endanger the inhabitants of a household with no possibility to seek refuge in the building or to reach the roof, thanks to a skylight, to be evacuated. Therefore the main protection measure in the PPR bylaw, whatever the level of flood, is to provide a refuge for the people allowing waiting for being evacuated.

The problem of the late implementation is not the only one concerning the vulnerability of the constructions. In Sallèles-d'Aude, impacted by the flood in 1999, the owners first complied with the PPR prescriptions consisting in particular to leave the ground floor free of occupation. But, little by little, the ground floor has been used again and sometimes rather quickly after the flood, 4 years after [14]. The vulnerability comes also from the non-compliance of the owners with the PPR prescriptions, because the damages are mostly compensated thanks to the insurance mechanism. So, the compensation occurs irrespective of conformity with the buildings [7].

Furthermore, the vulnerability comes also from the problem of illegal constructions without building permits in the flood-prone areas [(18) (12)]. After the flood disaster caused by the tempest Xynthia, the Ministry of Ecology decided to solve the problem of highly exposition to flood by enforcing a friendly land acquisition procedure. Indeed, the French prevention framework provides such a procedure. In this case, the households or the very little enterprises (less than 20 salaries) are bought thanks to the Major Natural Hazard
Prevention Fund, called Barnier Fund created in 1995. The fund is financed by a levy on insurance premiums for natural disasters. The first phase of the procedure consisted in a survey to identify the households in acquiring. But, the survey in the territories impacted by Xynthia highlighted that numerous flooded households have been built without building permits. However, the Ministry decided to apply the friendly land acquisition for the illegal households [28]. The example of Xynthia is not the only one. In the Argens valley in the Var, a study that we made in 2003 concerning the flood prevention policy showed that many constructions along the rivers were illegal, because of the transformation little by little of garden sheds into households. This process is called in French "cabanisation".

To try to bring solutions concerning the vulnerability to floods, several PAPIs have been enforced in the case study department: two in the Aude department (2006-2014 and 2015-2020 concerning in particular protection works in Cuxac d'Aude) [www.aude.gouv.fr/]; a PAPI in the Gard department on each rivers [www.noe.gard.fr/]; one for the Argens river and its tributaries (2015-2020) [http://www.var.fr/].

As a conclusion, we can say that the late implementation of the prevention provisions and especially the PPRs have caused an increase in the vulnerability of the territories to flood risk and a lack of safety. The "zero risk" in the areas exposed to natural hazards does not exist. Risk and urbanisation coevolves together, but they have to be reconciled through a new orientation of the urban design toward a sustainable urban development [29]. That is why these last years, the orientation of the strategies concerning the floods have shift from protection against flood to management of flooding risks [(30) (31)]. The vulnerability to flood risk is so widely spread in many territories that it is difficult to solve all the problems. The main concern is also to ensure the safety of the people in floodable zones and so, the solution is also to increase the performance of the meteorological monitoring to be able to quickly inform the people exposed and to evacuate them. It is impossible to eradicate the floods in spite of numerous efforts to protect the properties against flooding events. From now on, we have to develop strategies" to live with floods" rather than "to fight floods". This change of orientation is a challenge for the planning design and for the management process. But, at that time and at a local scale, there is hardly any practical experience of the development of long term integrated urban flood risk management plans [27].

The answer to solve the problem of the vulnerability of the constructions and the safety of the people and goods cannot be unique. One of the solutions is the friendly land acquisition for the constructions destroyed or severely damaged by a flood, as it has been enforced after the tempest Xynthia. But, in the reality, the cost to solve all the problems of exposition to natural hazards 
is so huge, that is impossible to intervene for each of them. The Rouzeau reports written after the flood in the Var department in 2010 [20], recommends also maintaining the rivers and not obstructing the flow; prohibiting the constructions in the empty spaces of urban zones if they are in floodable zones; building water resistant constructions with a refuge inside; providing an adapted crisis management.

Our study is still in progress and the next step to complete this first result will consist in analysing the building permits to see the monitoring of the public authorities on the urban development in the flood-prone areas and whether the constructions are adapted to flood risk (e.g. a first floor, flood proof material).

\section{References}

1. Ministère de l'Ecologie, du Développement durable et de l'Energie (2011). Première évaluation nationale des risques d'inondation. Principaux Résultats - EPRI 2011.

2. Ducrocq, V., Belamari, S., Boudevillain, B., Bousquet, O., Cocquerez, P., Doerenbecher, A., Drobinski, P., Flamant, C., Labatut, L., Lambert, D., Nuret, M., Richard, E., Roussot, O., Testor, P., Arbogast, P., Ayral, P.-A., Van Baelen, J., Basdevant, C., Boichard, J.-L., Bourras, D., Bouvier, C., Bouin, M.-N., Bock, O., Braud, I., Champollion, C., Coppola, L., Coquillat, S., Defer, E., Delanoe, J., Delrieu, G., Didon-Lescot, J.-F., Durand, P., Estournel, C., Fourrié, N., Garrouste, O., Giordani, H., Le Coz, J., Michel, Y., Nuissier, O., Roberts, G., Said, F., Schwarzenboeck, A., Sellegri, K., Taupier-Letage, I., Vandervaere J.-P. (2013). HyMeX, les campagnes de mesures : focus sur les événements extrêmes en Méditerranée, la météorologie, 80, 37-47

3. Nones M. (2015). Implementation of the floods directive in selected EU member states. Water and Environment Journal 29, 412-419.

4. European Environment Agency (2002). Environmental Signals. Benchmarking the millennium. Environmental assessment report $\mathbf{9}$, $149 \mathrm{p}$.

5. Lara A., Sauri D., Ribas A. and Pavon D. (2010). Social perceptions of floods and flood management in Mediterranean area (Consta Brava, Spain). Natural Hazards and Earth System Sciences 10, 2081-2091.

6. Grislain-Letrémy C. and Villeneuve B. (2015). Prévention des catastrophes naturelles: viser le long terme sans attendre. Revue d'économie financière 1/117, 127-136

7. Pottier N., Penning-Roswell E., Tunstall S. and Hubert G. (2005). Land use and flood protection: contrasting approaches and outcomes in France and in England and Wales. Applied Geography 25, 127.

8. Sanseverino-Godfrin V. (2008). Le cadre juridique de la gestion des risques naturels, Collections
Sciences du Risque et du Danger, Edition Lavoisier, 86 p.

9. Moll R. (2005). Co-operation within Europe on flood management and spatial planning. In Szöllosi-Nagy A. and Zevenbergen C. (Eds). Urban Flood Management, A.A. Balkema Publishers, $160 \mathrm{p}$.

10. Erdlenbruch K., Thoyer S., Grelot F., Kast R. and Enjolras G. (2009). Risk-sharing policies in the context of the French Flood Prevention Action Programmes. Journal of Environmental Management 91, 363-369.

11. Vinet F. (2003). Géographie des risques. Crues et inondations dans la France méditerranéenne. Les crues torrentielles des 12 et 13 novembre 1999 (Aude, Tarn, Pyrénées-Orientales, Hérault). Editions du temps, Nantes, $224 \mathrm{p}$.

12. Huet P., Martin X., Prime J.-L., Foin P., Laurain C. and Cannard P. (2003). Retour d'expérience des crues de septembre 2002 dans les départements du Gard, de l'Hérault, du Vaucluse, des Bouches-duRhône, de l'Ardèche et de la Drôme. MEDD-IGE, $133 \mathrm{p}$.

13. Colombat P.-Y. (2012). Se donner les moyens de ses ambitions : les leçons des inondations du Var et du sud-est de la France. Rapport d'information $\mathrm{n}^{\circ}$ 775, 388 p.

14. Douvinet J., Defossez S., Anselle A. and Denolle A.-S. (2011). Les maires face aux plans de prevention du risque inondation (PPRI). L'espace géographique 1 (Tome 40), 31-46

15. Question écrite au Sénat $\mathrm{n}^{\circ} 04455$, JO Sénat 13/01/1994, p. 57

16. Projet de loi portant réforme du regime d'indemnisation des catastrophes naturelles. Etude d'impact, mars 2012

17. Vinet F. (2010). Le risque inondation. Diagnostic et gestion. Paris : Editions Tech \& Doc, Editions Lavoisier, Coll. «Sciences du danger», série Innovations, $318 \mathrm{p}$..

18. Calvet F. and Manable C. (2015). Xynthia 5 ans après : pour une véritable culture du risque dans les territoires. Rapport d'information, $94 \mathrm{p}$.

19. Lefrou C., Martin X., Labarthe J.-P., Varret J., Mazière B., Tordjman R. and Feuteun R. (2000). Les crues des 12,13 et 14 novembre 1999 dans les départements de l'Aude, de l'Hérault, des PyrénéesOrientales et du Tarn. Affaire IGE $n^{\circ} 00$ 004, 146 p.

20. Rouzeau M., Martin X. and Pauc J.-C. (2010). Retour d'expérience des inondations survenues dans le département du Var les 15 et 16 juin 2010, $87 \mathrm{p}$.

21. Cour des Comptes (2010). Les enseignements des inondations de 2010 sur le littoral Atlantique (Xynthia) et dans le Var, 299 p.

22. Anziani A. (2010), Conséquences de la tempête Xynthia. Rapport d'information, $100 \mathrm{p}$.

23. Barroca B. and Pottier N. (2013). L'application territoriale du risque et de la vulnérabilité : à la recherche de démarches d'évaluation opérationnelles à destination des acteurs locaux. In 
Bresson M., Geronimi V., Pottier N. (dir.) Vulnérabilités: questions de recherches en sciences sociales, 277-292

24. Kreibich H. and Thieken A. H. (2009). Coping with floods in the city of Dresden, Germany. Natural Hazards 51, 423-436

25. Bubeck P., Botzen W. J. W., Kreibich H. and Aerts J. C. J. H. (2012). Long-term development and effectiveness of private flood management measures: an analysis for the German part of the river Rhine. Natural Hazards and Earth System Sciences 12, 3507-3518.

26. Poussin K. J., Wouter Botzen W. J. and Aerts J. C. J. H. (2015).Effectiveness of flood damage mitigation measures: Empirical evidence from Frecnh flood disasters. Global Environmental Change 31, 74-84.

27. Gersonius B., Zevenbergen C. and van Herk S. (2008). Managing flood risk in the urban environment: linking spatial planning, risk assessment, communication and policy. In Adaptive and Integrated Water Management, 263-275

28. Brouant J.-P. (2014). À propos des suites de la tempête Xynthia : petits arrangements avec les constructions illégales. Annales de géographie 2014/6 ( ${ }^{\circ}$ 700), 1381-1392.

29. Pottier N. and Barroca B. (2013). Du concept à la mesure de la vulnérabilité aux risques naturels : mutations et ouverture dans l'analyse géographique. In Bresson M., Geronimi V., Pottier N. (dir.) Vulnérabilités: questions de recherches en sciences sociales, 128-150

30. Mostert E. and Junier S. J. (2009). The European Flood Risk Directive: Challenges for Research. Hydrological and Earth System Sciences, 6(4), 4961-4988.

31. Müller U. (2013). Implementation of the Flood Risk management Directive in Selected European Countries. International Journal of Disaster Risk Science 4(3), 115-125. 